Bufl. Mater, Sci, Vol 15, No. 2, Aptil 1992, pp. 131-141. C Printed in India.

\title{
Thermomechanical properties and microstructure of alumina-zirconia
}

\author{
B L MITRA, N C BISWAS and P S AGGARWAL \\ Central Glass and Ceramic Research Institute, Caleutia 700032 , Jndia \\ MS received 28 August 1990; revised 30 April 1991
}

\begin{abstract}
Alsstract. $\mathrm{Al}_{2} \mathrm{O}_{3}-\mathrm{ZrO}_{2}$ composites were prepared in two compositional ranges. 15 wt $\%$ $\mathrm{Z}_{\mathrm{CO}} \mathrm{O}_{2}$ and $29 \mathrm{wt} / \mathrm{Z} \mathrm{ZrO}_{2}$ with or without yttria or magnesia stabilizers. While $1.5 \mathrm{wt} \% \mathrm{X}_{2} \mathrm{O}_{3}$. produtced tetragonal $\mathrm{ZrO}_{2}$ and fine grain microstructure, the $4.5 \mathrm{w} \% \mathrm{Y}_{2} \mathrm{O}_{3}$ developed cubic and tetragonal $\mathrm{ZrO}_{2}$ with similar microstructure $\mathrm{Al}_{2} \mathrm{O}_{3}$ with $29-5 \mathrm{wt} \% \mathrm{ZrO}_{2}-1 \cdot 5 \mathrm{wt} \% \mathrm{Y} \mathrm{Y}_{2} \mathrm{O}_{3}$ composition had the highost strength $\left(3,300 \mathrm{~kg} / \mathrm{cm}^{2}\right)$. The bending strength temained more or less the same after the first thermal slock, and then it decreased gradually, but retained some strength after 20 cycles of quench. The load us displacentent curve became nonlinear atter thermal shock possibly because of formation of microctacks which could be seen by microstructural staldies.
\end{abstract}

Keyworls. Alumina-zirconila conposites; thermal shock resistance; mictocracks; inelasticity.

\section{Introduction}

It is well-known that dispersion of zirconia in alumina substantially improves its strength (Hori et al 1986; Marshall 1986; Lange and Miller 1987; Wang and Stevens 1988; Sritivasa Rao and Cannon 1989) and thermomechanical properties. The grain growt th of alumina is also hindered by the addition of zirconia (Lange and Hirlinger 1984; Lin and Lu 1988), but the densification rate of alumina during sintering is reduced linearly willh $\mathrm{Z}_{\mathrm{rO}}$ addition (Majumdar et al 1986). The strengthening of alumina by zirconia depends on several factors. During stress-induced martensitic phase transformation of telragonal zirconia particles to the monoclinic form, considerable stress is absorbed from the stress field of propagating cracks (Rühle et al 1986). The residual stresses around which already transformed monoclinic zirconia can cause microcracking and give further strengthening (Hori et al 1986). Cubic zirconia is also a toughening agent of alumina ceramics sintered in air (Kibbel and Heuer 1984). Crack deflection also plays an important role (Wang and Stevens 1988). Annealing at higher temperature $\left(1200^{\circ} \mathrm{C}\right.$ or above) gives rise to grain coarsening effect (Kibbel and Heuer 1986). The intergranular $\mathrm{ZrO}_{2}$ particles appear to coarsen by coalescence as particles are dragged by migrating $\mathrm{Al}_{2} \mathrm{O}_{3}$ grain boundaries (Nettleship and Stevens 1987). This is controlled by $\mathrm{ZrO}_{2}-\mathrm{Al}_{2} \mathrm{O}_{3}$ diffusion kinetics. The intragranular particles coarsen at a rnuch slower rate (Kibbel and Heuer 1986). In gencral, $\mathrm{Al}_{2} \mathrm{O}_{3}-7 \mathrm{rO}_{2}$ composites would often cope with appreciable thermal stresses. In the present work, the bending strength of as-fired, annealed and thermal-shocked samples of $7 \mathrm{rO}_{2}-\mathrm{Al}_{2} \mathrm{O}_{3}$ composites containing 13.5 to $29 \mathrm{wt} \% \mathrm{ZrO}_{2}$ composites is compared. Microstructure and phase analysis of the composites are also presented. 
Table 1. Batch composition, water absorption and bulk density.

\begin{tabular}{|c|c|c|c|c|c|}
\hline \multirow{2}{*}{$\begin{array}{l}\text { Material } \\
w t \%\end{array}$} & \multicolumn{5}{|c|}{ Batch } \\
\hline & A & $\mathrm{B}$ & $\mathrm{C}$ & $\mathrm{D}$ & $\mathrm{E}$ \\
\hline $\mathrm{Al}_{2} \mathrm{O}_{3}$ & 85.00 & 84.0 & 7000 & $69 \cdot 00$ & 66.99 \\
\hline $\mathrm{ZrO}_{2}$ & $15 \cdot 00$ & 14.50 & $29 \cdot 00$ & $29 \cdot 50$ & $28 \cdot 64$ \\
\hline$Y_{2} O_{3}$ & - & 1.50 & - & 1.50 & $4 \cdot 37$ \\
\hline $\mathrm{MgO}$ & - & - & 1.0 & $-\pi$ & - \\
\hline $\begin{array}{l}\left(\mathrm{MgCO}_{3}\right) \\
\text { Water absotption(\%) }\end{array}$ & $1-53$ & 0.85 & $\begin{array}{l}(2+1) \\
2 \times 35\end{array}$ & 0.53 & 1.78 \\
\hline $\begin{array}{l}\text { Bulk density } \\
(\mathrm{g} / \mathrm{CC})\end{array}$ & 3.920 & 3.976 & $3 \cdot 920$ & $4 \cdot 165$ & 3.950 \\
\hline $\begin{array}{l}\text { Theoretical } \\
\text { density (wo) }\end{array}$ & 92.9 & $95-8$ & $88 \cdot 3$ & 940 & $91 \cdot 9$ \\
\hline
\end{tabular}

\section{Experimental}

Five compositions marked $A, B, C, D, E$ (table 1) with stabilizing agents $Y_{2} \mathrm{O}_{3}$ as well as $\mathrm{MgO}$ (batch C) in some cases were prepared by wet ball milling for $30 \mathrm{~h}$. Bars of approximate dimensions $78 \times 18 \times 4-5 \mathrm{~mm}$ werc made by dry-pressing at $650 \mathrm{~kg} / \mathrm{cm}^{2}$ followed by isostatic pressing at $3,165 \mathrm{~kg} / \mathrm{cm}^{2}(45,000 \mathrm{psi})$. Two-step sintering combining $1 \mathrm{~h}$ isothermal heating at $1400^{\circ} \mathrm{C}$ and followed by 90 min soaking at $1560-1580^{\circ} \mathrm{C}$ was adopted. The fired sample surfaces werc ground by 220 and 400 mesh SiC powders. The samples were annealed by heat treating the sample at $1140^{\circ} \mathrm{C}$ for $30 \mathrm{~min}$ before quenching. Thermal shock test was performed by thermal cycling the samples between $1200^{\circ} \mathrm{C}$ and drought-free air, giving at least 10 min soaking at $1200^{\circ} \mathrm{C}$ every time. Three-point bending strength and Young's modulus were determined by Instron. Fractured surfaces were etched by $15 \% \mathrm{HF}-20 \% \mathrm{HCI}$ mixed etchant and observed in scanning electron microscope (SEM). X-ray diffraction analysis (XDA) was carried out using Cu target. Bulk density was determined by the Archemedes method.

\section{Results and discussion}

The firing shrinkage of the samples averaged at $20-23 \%$, a value, which was accounted for in making precision technical ceramics. Bulk density and water absorption values were recorded as shown in table 1 . The use of yttria improved the density with respect to that obtained by the use of $\mathrm{MgO}$ additive (batch Cl. Small addition of $\mathrm{MgO}$ had a beneficial effect on sintering of $\mathrm{Al}_{2} \mathrm{O}_{3}-\mathrm{ZrO}_{2}$ (Kosmac et al 1982) and acted as a stabilizer for $\mathrm{ZrO}_{2}$ (Bansal and Heuer 1975; Zoz et al 1980). One MgO-composition of $1 \mathrm{wt} \% \mathrm{MgO}$ was studied to get a good produet.

By X-ray diffraction it was found that addition of $Y_{2} \mathrm{O}_{3}$ increased tetragonal phase retertion. The diffractogram traces for (111) $m,(111) t, c$ and (111) $m$ reflections were as shown in figure 1 . The high angle diffaction for $(400) t,(400) c,(004) t$ is as shown in figure 2. Composition B was almost free from monoclinic phase since (111) $\mathrm{m}$ reflection at $28.4^{\circ}$ and $(11 \overline{1}) \mathrm{m}$ reflection at $31.5^{\circ}$ were found negligible. High angle 


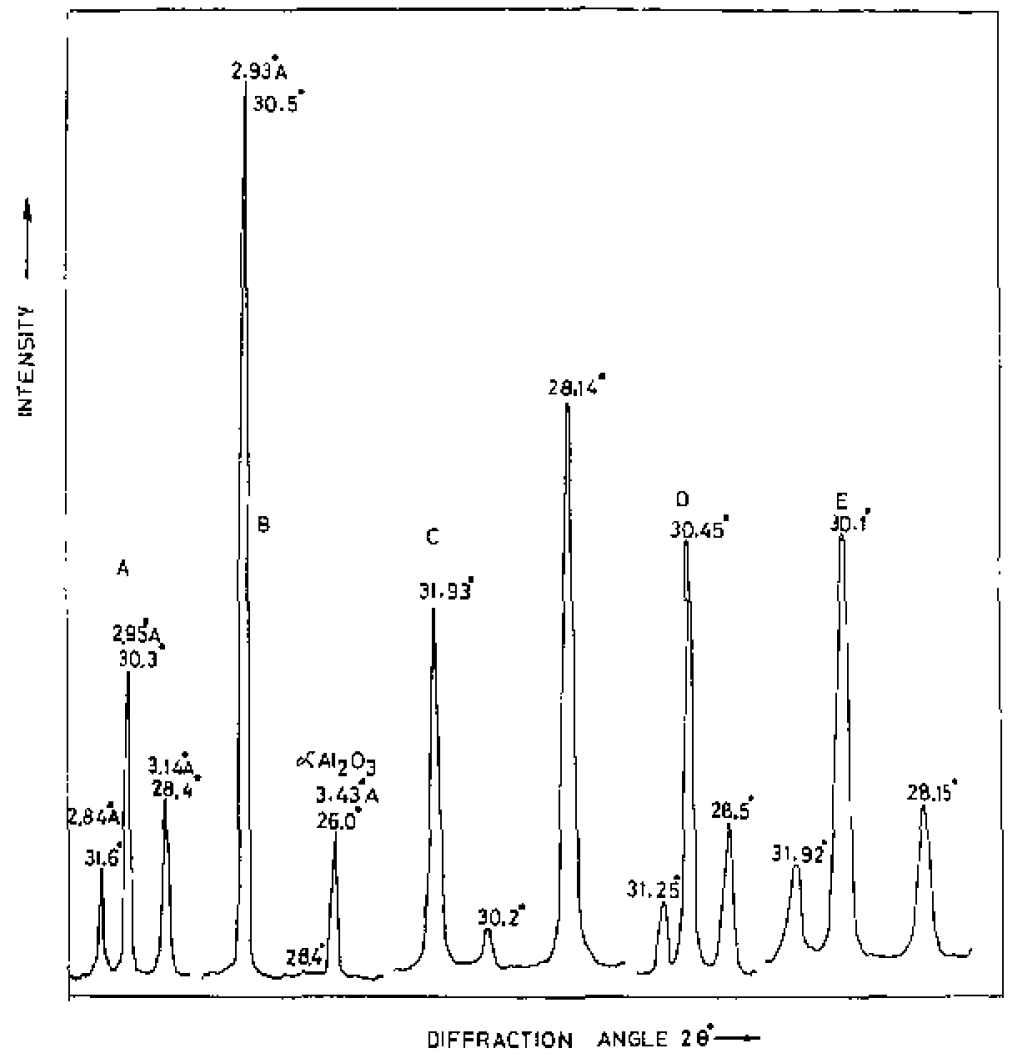

Figuje 1. Low argle $X$-ray diliraction (peaks) diagrams.

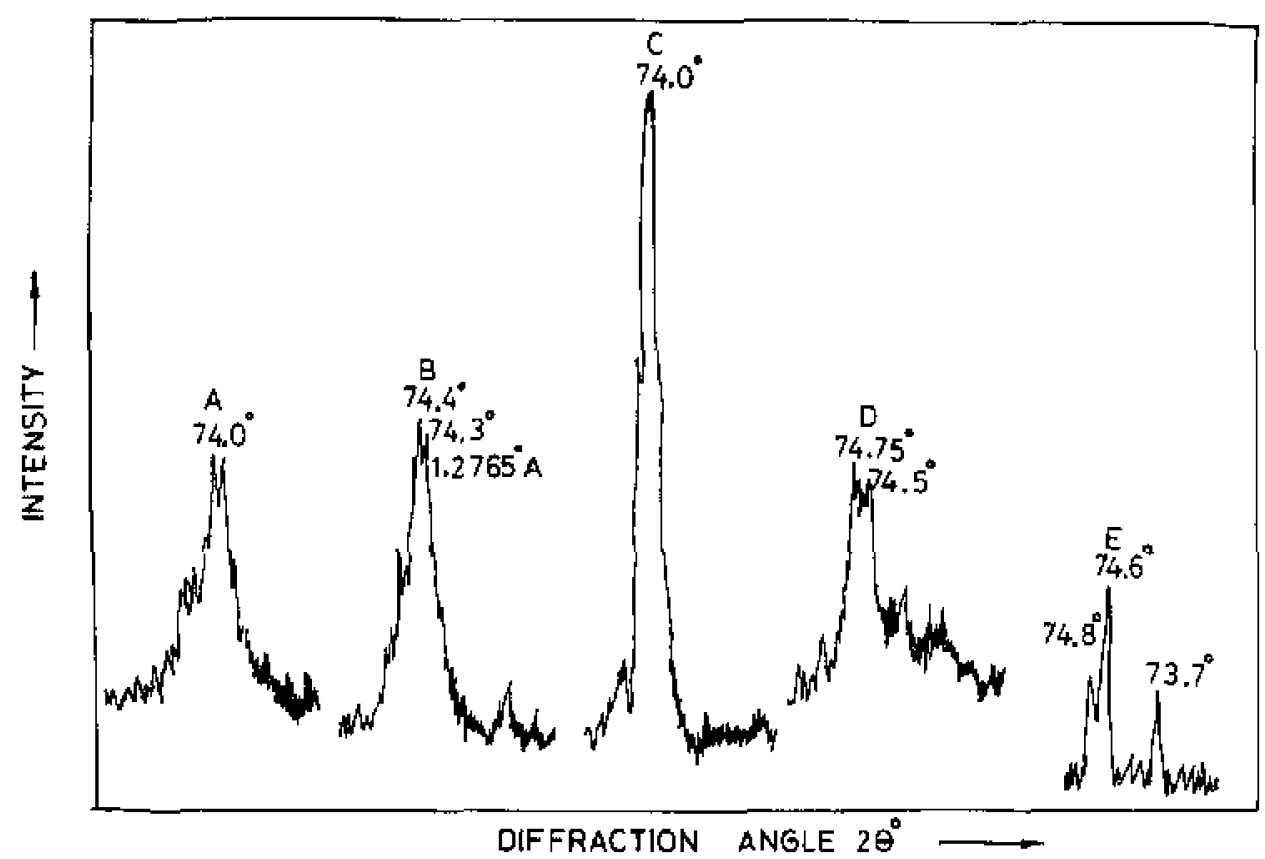

Figure 2. High angle X-ray diffraction (peaks) diagrams. 
Table 2. Bending strength (in $\mathrm{kg} / \mathrm{cm}^{2}$ ) alter different thennal cycling.

\begin{tabular}{|c|c|c|c|c|c|c|c|}
\hline Batcl & $\begin{array}{l}\text { Saniples } \\
\text { as such }\end{array}$ & $\begin{array}{l}1 \text { trols } \\
\text { thermal } \\
\text { shock }\end{array}$ & $\begin{array}{c}3 \text { ejcles } \\
\text { of theritial } \\
\text { shock }\end{array}$ & $\begin{array}{l}5 \text { cyoles } \\
\text { of thworial } \\
\text { shock }\end{array}$ & $\begin{array}{l}10 \text { cycies } \\
\text { of thermal } \\
\text { shock }\end{array}$ & $\begin{array}{l}15 \text { cycies } \\
\text { of thermit } \\
\text { shock }\end{array}$ & $\begin{array}{c}20 \text { cycles } \\
\text { of therma } \\
\text { shock }\end{array}$ \\
\hline A & $\begin{array}{l}2,250 \\
\pm 200\end{array}$ & $\begin{array}{l}2,060 \\
\pm .200\end{array}$ & 560 & 570 & 520 & - & 404 \\
\hline B & $\begin{array}{c}2,960 \\
\pm 200\end{array}$ & $\begin{array}{l}2,640 \\
\pm 200\end{array}$ & 712 & $600 \pm 90$ & 660 & 483 & 438 \\
\hline C & $\begin{array}{l}1,850 \\
\pm 300\end{array}$ & $\begin{array}{l}4,890 \\
\pm 300\end{array}$ & 646 & 604 & 542 & 463 & 270 \\
\hline$D$ & $\begin{array}{l}3,000 \\
-300\end{array}$ & $\begin{array}{l}3,290 \\
\pm 300\end{array}$ & 780 & 740 & 660 & 538 & 471 \\
\hline $\mathrm{E}$ & $\begin{array}{l}2,430 \\
\pm 200\end{array}$ & $\begin{array}{l}2,350 \\
\pm 200\end{array}$ & 608 & 650 & 710 & 446 & 243 \\
\hline
\end{tabular}

diffraction of sample $B$ gave (400) reflection at $74 \cdot 4^{*}$ which according to Benedetti et of (1989) was for tetragonal $\mathrm{ZrO}$. Other compositions $(A, C, D, E)$ contained monocinic zirconia, $\alpha-\mathrm{Al}_{2} \mathrm{O}_{3}$ and anouber $\mathrm{ZrO}_{2}$ phase. It was difficult to distinguish between tetragonal and cubic $\mathrm{ZrO}_{2}$ from (11) reflection at 30.420. But from the high angle difraction of figure 2 , compositions $A$ and $C$ were found to contain cubic $\mathrm{ZrO}_{2}$ (along with monoclinic $\mathrm{ZrO}_{2}$ ). Composition $\mathrm{D}$ contained tetragonal along with monoclinic $\mathrm{ZrO}_{2}$. Composition $\mathrm{E}$ developed tetragonal $\mathrm{ZrO}_{2}\left(74 \cdot 6^{\circ} 26\right)$, cubic $\mathrm{ZrO} \mathrm{O}_{2}$ $\left(73 \cdot 7^{\circ} 2 \theta\right)$ and monoclinic $\mathrm{ZrO}_{2}\left(28-15^{\circ} 2 \theta\right)$ together. The formation of cubic phase in A was probably due to the impurities from raw materials as well as from grinding the batches.

The three-point bending strength of unannealed samples was higher in the case of $15 \mathrm{wt} \% \mathrm{ZrO}_{2}$ batches and decreased considerably at $29 \mathrm{wt} \% \mathrm{ZrO}_{2}$ addition in batch $\mathrm{C}$ (table 2). But when $1.5 \mathrm{w} \% \mathrm{Y}_{2} \mathrm{O}_{3}$ was added to $29 \mathrm{wt} \% \mathrm{ZrO}_{2}$ batch, the highest strength was obtained. However when $\mathrm{Y}_{2} \mathrm{O}_{3}$ was increased to about $4.5 \%$ the strength decreased. This could have been due to the formation of non-transformable cubic $\mathrm{ZrO}_{2}$ in place of tetragonal $\mathrm{ZrO}_{2}$ (Nettleship and Stevcns 1987 ). The bending strengh remained more or less the same alter the first thermal shock, increased on first cycle in case of batches $C$ and $D$, after that the strength decreased abruptly with increasing number of thermal shock cycling. This was evident from the results of third cycles. But even after 20 cycles of thermal shocks, these samples retained appreciable strength (240 to $\left.470 \mathrm{~kg} / \mathrm{cm}^{2}\right)$. Yuan $e t$ al (1986) reported lower strength of zirconid-mullite on thermal cycling (aftcr 3 thermal shocks $460-1000 \mathrm{~kg} / \mathrm{cm}^{2}$ ). However, in our case, the load vs displacement curve was found to be nollinear, especially after thermal shock cycling (figures $3 \mathrm{a}-\mathrm{e}$ ). The plastic deformation and the nature of the curves after thernal shock treatment suggested that microcracks were formed in the samples due to thermal shock and these microcracks were absorbing some amount of stress giving rise to plasticity.

Nonlinear stress-strain behaviour and plastic deformation in transformationtoughened materials have also been discussed by several workers (Marshall 1986; Matsui et al 1986; Heuer et al 1986; Swain 1990; Wu and Chen 1990). The pseudoplastic behaviour in these materials possibly arises both from stress-induced martensitic transformation as well as microcracking. Marshall (1 986) observed linear stross-strain 

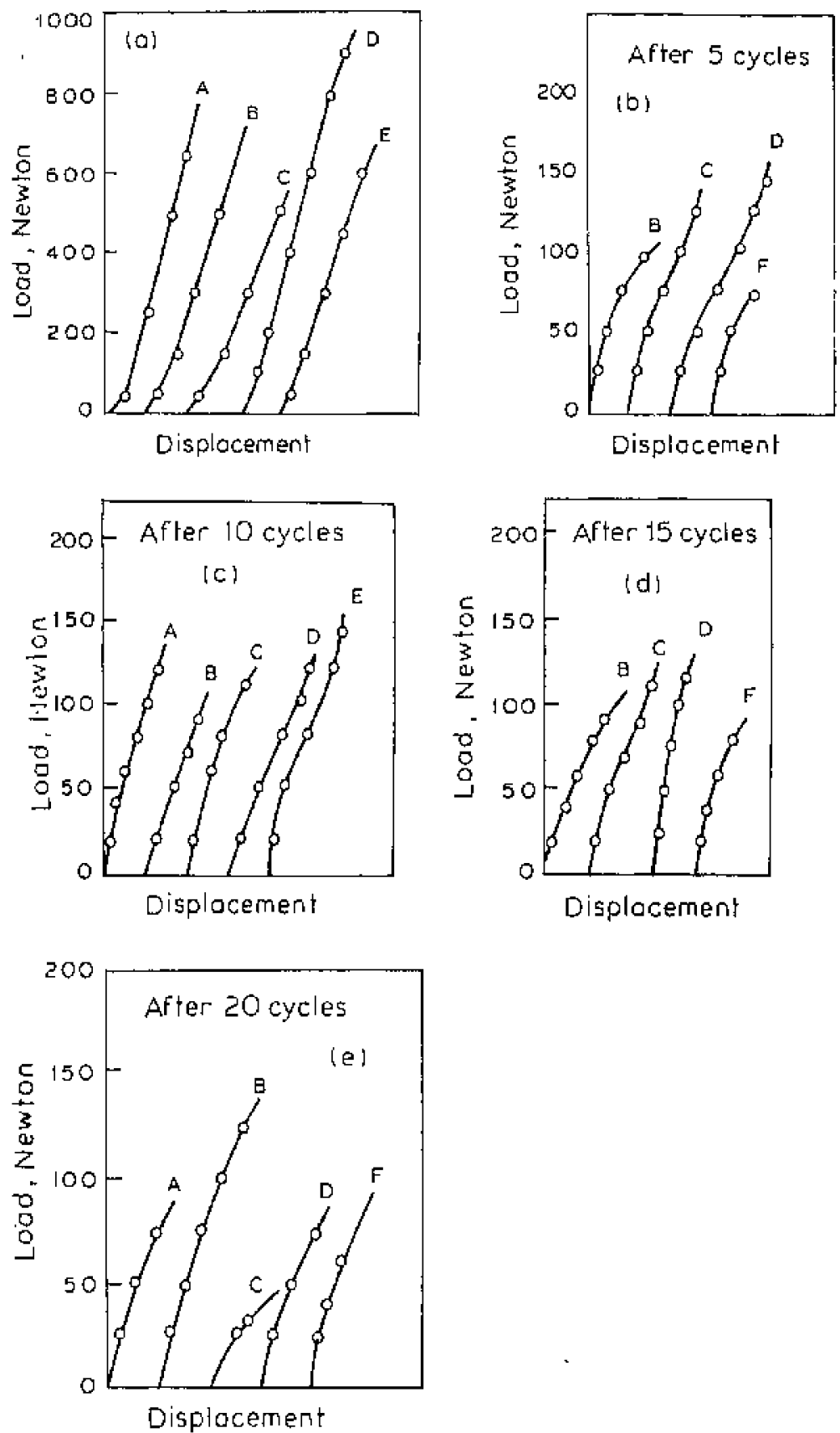

Figure 3. Load-displacement curyes on flexural bending.

behaviour in overaged material, whereas nonlinear behaviour was seen in the toughened material. The increasing nonlinear component was evident at higher strains.

Young's modulus $(E)$ was determined from the load displacement curve of 3-point bending test, from the following equations,

$$
E=W l^{3} / 48 I \delta
$$


Table 3. Young's modulus (in $\times 10^{6} \mathrm{~kg} / \mathrm{cm}^{2}$ ) after different thermal cycling.

\begin{tabular}{lccccccc} 
Batch & $\begin{array}{c}\text { Sample } \\
\text { as such }\end{array}$ & $\begin{array}{c}\text { Afnealed } \\
1 \text { cycle }\end{array}$ & $\begin{array}{c}3 \text { cycles } \\
\text { of thermal } \\
\text { shock }\end{array}$ & $\begin{array}{c}5 \text { cycles } \\
\text { of thermal } \\
\text { shock }\end{array}$ & $\begin{array}{c}10 \text { cycles } \\
\text { of themal } \\
\text { shock }\end{array}$ & $\begin{array}{c}15 \text { cycles } \\
\text { of thermal } \\
\text { shock }\end{array}$ & $\begin{array}{c}20 \text { cyctes } \\
\text { of thermal } \\
\text { shock }\end{array}$ \\
\hline A & 1.64 & 1.45 & 0.8 & 0.7 & 0.5 & - & 0.80 \\
C & 2.00 & 1.95 & 1.2 & 1.2 & 0.7 & 0.80 & 0.83 \\
D & 1.33 & 0.97 & 0.7 & 0.65 & 0.4 & 0.43 & 0.50 \\
$\mathrm{E}$ & 1.50 & 0.98 & 0.75 & 0.6 & 0.5 & 0.81 & 0.52 \\
\hline
\end{tabular}

where the moment of inertia,

$$
I=b t^{3} / 12
$$

and deflection

$$
\delta=\frac{a \times 2 \mathrm{~mm}}{\text { Chart drive }} \times \text { cross head speed. }
$$

Herc $W$ is load, $I$ the span, $b$ the breadth, $t$ the thickness and $a=$ chart reading corresponding to $W$.

Batches $A$ and $B$ had higher Young's modulus than batches C, D and E, although the strength of the composition $D$ was the highest. This was probably because batches $A$ and $B$ contained higher quantities of alumina which was more elastic than $\mathrm{ZrO}_{2}$. Young's modulus decreased on thermal shock trealment but started increasing after 15 cycles. Intergranular pores and cracks relaxed residual stresses (Buresh 1984). The reduction in $E$ was indicative of considerable microcrack development (Swain 1990) on thermal shock. The rise of $E$ after 15 cycles could have been due to the rcsistance to crack-growth by network of microcracks developed.

The scanning electron micrographs (SEM) of fractured surfaces are shown in figure 4(a) to $4(f)$. Figures $4 \mathrm{a}$ and $4 \mathrm{~b}$ are fractographs of batches $\mathrm{A}$ and $\mathrm{B}$ prepared from ball-milled alumina and hence the grains are of bigger sizes. The remaining figures are those of samples made from vibro-energy-milied alumina which is much finer than ball-milled alumina. Grain size and pore sizes were much smaller in these cases. It was difficult to distinguisl between alunina and zirconja grains in scanning electron mictographs without back scattering. But from XRD analysis and by comparisor with the reported microstructure of other workers (Heuer et al 1982; Kibbel and Heuer 1986), small round and irregular-shaped grains were considered as zirconia. Intergranular zirconia crystallites as well as few intragranular $\mathrm{ZrO}_{2}$ phase were seen enrneshed in $\mathrm{Al}_{2} \mathrm{O}_{3}$ crystals. The surrounding $\mathrm{Al}_{2} \mathrm{O}_{3}$ grains exert matrix constraint upon $\mathrm{ZrO}_{2}$ grains thereby reducing the tendency of $\mathrm{ZrO}_{2}$ grains to transform. At higher magnification (figure 2d), intragrantlar precipitates are revealed as engraved within the $\mathrm{Al}_{2} \mathrm{O}_{3}$ crystallites. In the micrographs of batches $\mathrm{B}$ and $\mathrm{D}$, strong grain-to-grain bonding took place as a result of good sintering. The grain size of aiumina was comparatively smaller in $\mathrm{Y}_{2} \mathrm{O}_{3}$ containing batches B (average $3.45 \mu \mathrm{m}$, pot mjlled batch) and $D$ (average $1.76 \mu \mathrm{m}$, vibro energy-milled batch). The average grain size of $\mathrm{Al}_{2} \mathrm{O}_{3}$ in batch $\mathrm{A}$ was $7.3 \mu \mathrm{m}$ (pot-milled batch) and in batch $\mathrm{C}, 2.7 \mu \mathrm{m}$ (Vibro energy-milled batch), yttria had more pronounced grain growth retarding effect 

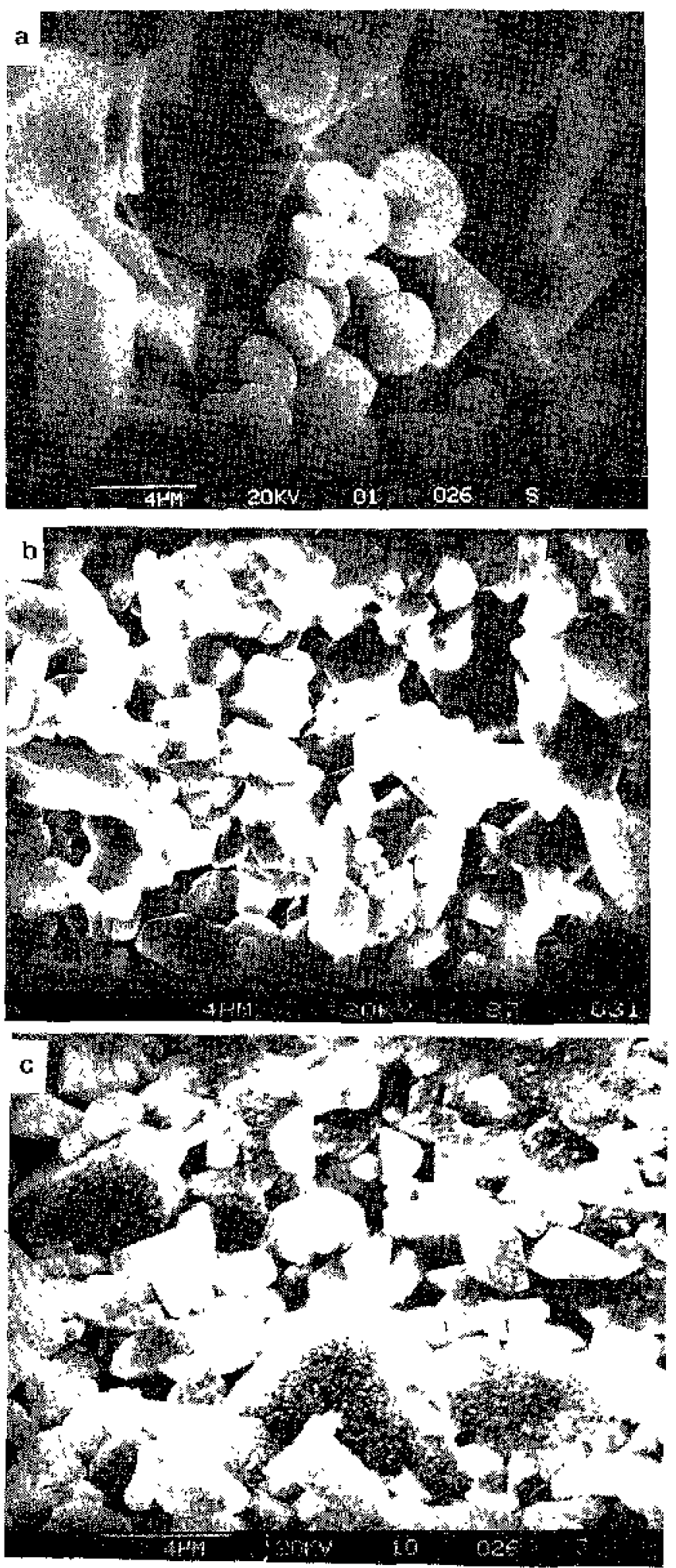

Figure $4(a-c)$. For caption, see p. 138. 

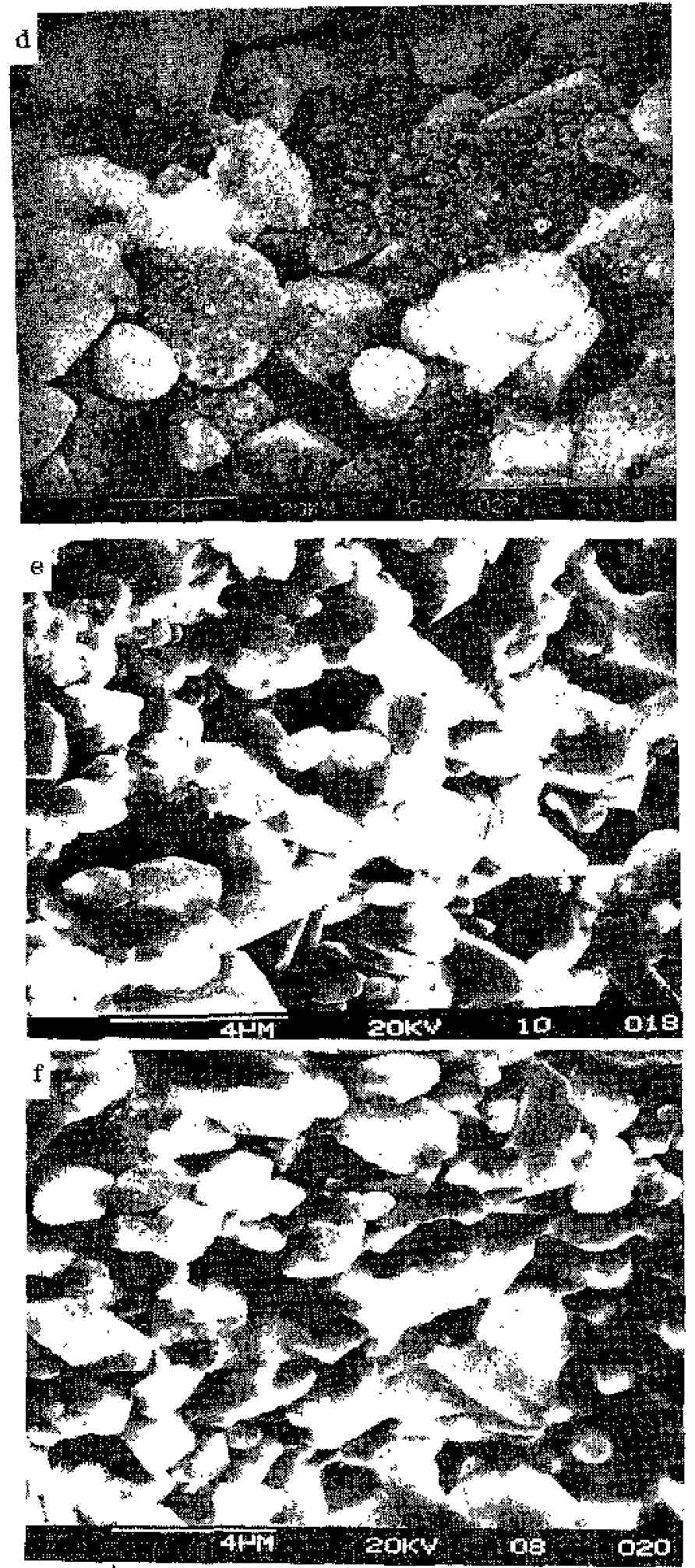

Figure 4. SEM fractographs. a. Composition A from ball-milled alumina, b. Conpusition B [rom ball-milled alumina. c. Composition C from vibro-energy milled $\mathrm{Al}_{2} \mathrm{O}_{3}$, d. Composition $C$ with higher magnification, e. Composition $D$ from vibro-energy milled $\mathrm{Al}_{2} \mathrm{O}_{3}$ and $\mathrm{f}$. Composition $\mathrm{E}$ from vibro-energy milled $\mathrm{Al}_{2} \mathrm{O}_{3}$. 

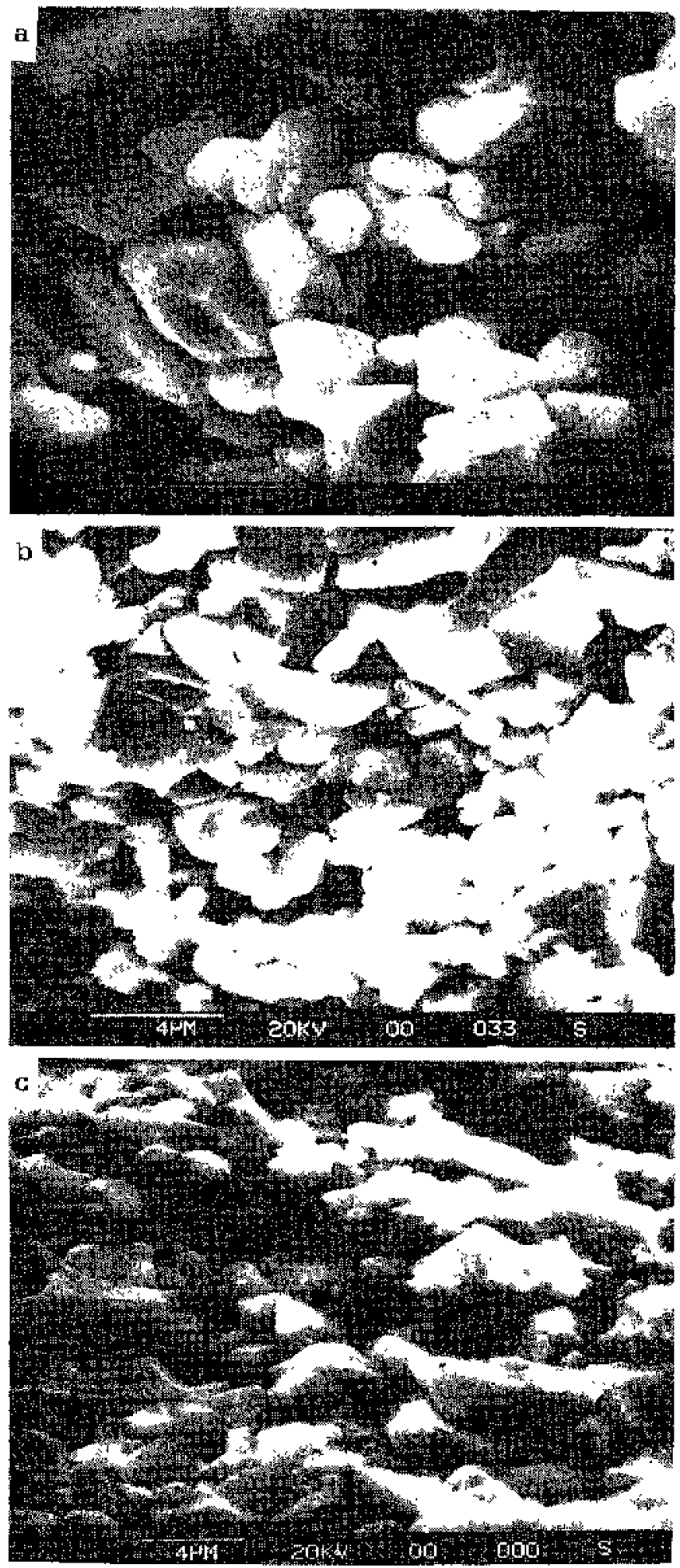

Figure 5. SEM fractographs after thermal shock test. a. Sainple $\mathbf{R}$ after 5 thermal shocks. b. Sample C after 5 thermal shocks. c. Sample $\mathrm{E}$ atter 10 thermal shocks. 
than magnesia in $\mathrm{Al}_{2} \mathrm{O}_{3}-\mathrm{ZrO}_{2}$ composites. Some pores were seen as black phases in the micrographs.

Figures $3 \mathrm{a}$ and $3 \mathrm{~b}$ show the microstructures of compositions $\mathrm{B}$ and $\mathrm{C}$ respectively after five thermal shock treatments. Figure $3 \mathrm{C}$ is for composition $E$ (thermal-cycled 10 times). In all these cases, grain-to-grain bonding bad weakened due to thermal cycling giving rise to separation of grains or formation of microcracks with dimensions similar to the grain size. Marshall (1986) observed formation of microctacks equivalent to the grain size under load. These microcracks absorb some energy during their subcritical growth under stress (microcrack toughening). Some plasticity was developed due to this effect. Examination in back-scaltered mode (Green 1982) would have clarilied the microcracks better.

Although open porosity was negligible in these materials as understood from water absorption values, a lot of pores were still seen in the microstructure. This atso agreed with theoretical density values shown in table 1 . Because of the presence of pores, the strength values were much less. Howcver, the presence of pores was beneficial in several applications; for example, in bioimplant, the presence of porosity was sometimes beneficial for bone growth. Thesc materiais were used as refractory materials by virtue of their good thermal shock rusistance and strength.

\section{Conclusions}

The following conclusions arc drawn from the above observations.

(i) $\mathrm{Al}_{2} \mathrm{O}_{3}-29.5 \mathrm{wt} / \mathrm{ZrO} \mathrm{ZrO}_{2}-1.5 \% \mathrm{Y}_{2} \mathrm{O}_{3}$ composition has the highest strength and $\mathrm{AJ}_{2} \mathrm{O}_{3}-15 \mathrm{w} \% \mathrm{ZrO}_{2}$ has a somewh at higher strength compared to $\mathrm{Al}_{2} \mathrm{O}_{3} \ldots$ $29 \mathrm{wt} \%-1 \mathrm{wt} \% \mathrm{MgO}$ composition.

(ii) Addition of $1.5 \mathrm{w} \% \mathrm{Y}_{2} \mathrm{O}_{3}$ has the beneficial effect of retaining tetragonal $\mathrm{ZrO}_{2}$ and producing fine-grained microstructure and good grain-to-grain bonding.

(iii) The increase of $\mathrm{Y}_{2} \mathrm{O}_{3}$ up to $4.5 \%$ causes formation of cubic-tetragonal-monoclinic zirconia and reduction in strength. The MgO-stabilized batch and the batch without any deliberate addition of stabilizer also had significant amount of cubic phase in addition to monoclinic $\mathrm{ZrO}_{2}$ probably because of the impurities.

(iv) The bending strength remained the same or slightly increased in some cases after the first thermal cycling; thereaftcr the strength decreased abruptly on repcated thermal shock cycling: but even after 20 cycles, the samples possessed some strength.

(v) Young's modulus also decreases on thermal shock treatment up to 15 th cycles, thereafter it increases. The nonlinear behaviour of elasticity or load-displacement diagram after thermal shock treatment is due to microcracks.

\section{Acknowledgements}

The authors thank Drs K K Phani, Suchitra Sen and Sri Dilip Ghosh for their kind technical assistance and Dr $\mathbf{J}$ Mukherji for suggestions.

\section{Refertnces}

Bansal G K and Heuer A H $1975 \mathrm{~J}$. Am. Ceram. Soc. 58235

Benedetti A, Fagherazzi G and Pinna F 1989 J. Am. Cesart. Soc. 72467 
Buresh F E 1984 in Advances in ceramics. Science and technology of zirconia $I$ (eds) N Claussen, $M$ Rïhle and $A \mathrm{H}$ Heuer (Cotumbus, Ohio; Am, Ceram. Soc.) 12 p 306

Green D J 1982 J. Am. Ceram. Soc, 65610

Heuer A H, Claussen N, Kriven W M and Rühle M $1982 \mathrm{~J}$. Am. Ceram. Soc. 65642

Heuer A H, Lange F F, Swain MV and Evans A G $1986 \mathrm{~J}$, Am. Coram. Soc. $69 \mathrm{i}$-jy

Hari S, Yoshimura M and Somiya S $1986 \mathrm{~J}$. Am. Ceram. Soc. 69169

Kibbel B W and Heuer A II 1984 in Adoances in ceranics. Science and technology of airconia II (eds)

N Claussen, M Rühle and A H Heuer (Columbus. Ohio; Am. Ceram. Soc) 12 p 415

Kibbel $\mathrm{B}$ and Heuer A H 1986 J. Am Cerom. Soc. 69231

Kosmac T, Wallace J S and Clanssen N 1982 J. Am. Cercm. Soc. 65666

Lange F F and Hirlinger M M 1984 .J. Am. Ceram. Soc. 67164

lange F F and Miller K T 1987 J. Am. Ceram. Soc. 70896

Lin J T and Lu Hy 1988 Ceram. Int. 14251

Majunder R, Gilbert E and Brook R J 1986 Br. Ceram. Trans. J. 85156

Marshall D B 1986 J. Am. Ceram. Soc. 69173

Matsui M, Sona T and Oda I 1986 J. Am. Ceram. Soe. 69198

Vettleslip I and Stevens R 1987 Int. J, Wigh Tech. Ceram 31

Rühle M. Claussen N and Heuer A H 1986 J. Am. Ceram. Soc. 69195

Srimivasa Rao A and Cannon W R 1989 Ceram. Intert. 15179

Swain M V $1990 \mathrm{~J}$. Am. Ceram. Soc. 73621

Wang J and Stevens R. $1988 \mathrm{~J}$. Mater. $\mathrm{Sci} .23804$

Wu Xin and Chen I W $1990 \mathrm{~J}$. Am. Ceram. Soc. 73746

Yuan Q M, Tan J Q and Jin Z O 1986 J. Am. Ceram. Soc 69265

Zox E I, Karaulov A G, Rudyak I N, Gul'ko N V and Karyakina E L 1980 Inorq. Mater. 16728 